Article

\title{
Occurrence of Mycotoxigenic Fusarium Species and Competitive Fungi on Preharvest Maize Ear Rot in Poland
}

\author{
Karolina Gromadzka ${ }^{1, * \mathbb{D}}$, Lidia Błaszczyk ${ }^{2}$, Jerzy Chełkowski ${ }^{2}$ and Agnieszka Waśkiewicz ${ }^{1}$ \\ 1 Department of Chemistry, Poznań University of Life Sciences, ul. Wojska Polskiego 75, 60-625 Poznań, \\ Poland; agnieszka.waskiewicz@up.poznan.pl \\ 2 Institute of Plant Genetics, Polish Academy of Sciences, ul. Strzeszyńska 34, 60-479 Poznań, Poland; \\ lgol@igr.poznan.pl (L.B.); jche@igr.poznan.pl (J.C.) \\ * Correspondence: karolina.gromadzka@up.poznan.pl; Tel.: +48-61848-78-26
}

Received: 20 March 2019; Accepted: 11 April 2019; Published: 15 April 2019

\begin{abstract}
Maize has become one of the most important crops for food and feed production-both as a silage and crop residue worldwide. The present study aimed to identify the co-occurrence of Fusarium subglutinans, Fusarium verticillioides, Trichoderma atroviride, Sarocladium zeae, and Lecanicillium lecanii on maize ear rot. Further, the accumulation of mycotoxins as secondary metabolites of Fusarium spp. in maize ear samples was also analyzed. Maize ear samples were collected between 2014 and 2017 from two main maize growing areas in Poland (Greater Poland and Silesia region). A significant difference was found in the frequency of two main Fusarium spp. that infect maize ears, namely F. subglutinans and F. verticillioides. In addition to Fusarium spp. T. atroviride, S. zeae, and L. lecanii were also identified. T. atroviride species was found in 14\% of maize samples examined between 2014 and 2017, particularly with a high percentage of Trichoderma spp. recorded in 2014, i.e., in 31\% of samples. However, mycotoxin content (beauvericin and fumonisins) varied, depending on both the location and year of sampling. The interaction of fungi and insects inhabiting maize ear and kernel is very complex and not yet elucidated. Therefore, further research is required in this area.
\end{abstract}

Keywords: mycotoxins; maize ear rot; Trichoderma; Sarocladium; Lecanicillium; Fusarium species

Key Contribution: Fusarium species and endophyte: Trichoderma spp. and Sarocladium zeae were found in field maize ears with high frequency in Poland from 2014 to 2017

\section{Introduction}

In Poland, maize (Zea mays) is, one of the major cereal grains, cultivated every year in an area of approximately one million ha. From year to year, its importance in the cultivation is growing [1]. It is also an important continuous breeding progress, which allows for a significant reduction in the thermal needs of maize. Growers provide us with more and more productive varieties suitable for our climatic conditions. The result is a more precise variety matching the climate and geographical region as well as the differentiated direction of use.

An important disadvantage of maize is its susceptibility to Fusarium pathogens [2]. They attack plants at different developmental stages, leading to root rot, stalk rot, and ear rot, which are considered the most important disease of crop worldwide [3]. The prevailing pathogen species can vary over the years depending on various factors, such as the continent and region, agroecological conditions $[4,5]$, insect damage [6], other stress factors and susceptibility of cultivars (hybrids) to infection by Fusarium species [7]. There are a number of pathways by which Fusarium species may infect kernels, resulting in kernel rot or symptomless infection. The incidence of symptomless infection is usually higher than 
the incidence of kernel rot [8,9]. Kernel infection by any of these fungi can reduce yields and quality, and result in mycotoxin accumulation in grain, such as deoxynivalenol (DON), zearalenone (ZEA), fumonisins (FBs), beauvericin (BEA), enniatins (ENNs), and moniliformin (MON) [7,10-13].

In Poland, Fusarium species occurrence and their mycotoxin production have been studied since the middle of the 20th century. Until the 1990s, the climate of this country has been described as temperate with relatively cold winters and warm summers. In recent years, the climate has become much warmer, with, frequent, day-to-day and year-to-year variability in the weather patterns noted. As a consequence, the occurrence of other species, such as F. verticillioides or F. subglutinans, began to increase. Despite this, the level of mycotoxins in cereal grain samples collected in Poland was usually lower in comparison to other European countries [14-16].

The latest research, which was carried out by NUTRIAD (NUTRIAD Mycotoxin Survey, 2017), showed that $100 \%$ of the maize kernels from Poland were contaminated with DON, $94 \%$ with ZEA and $72 \%$ of the samples contained FBs. The average concentrations of mycotoxins were below EU recommendation levels. The ZEA average concentration was $257 \mu \mathrm{g} \mathrm{kg}^{-1}$, which is high, especially for sows and piglets. The results also showed a high average concentration of DON, $1198 \mu \mathrm{g} \mathrm{kg}^{-1}$. The maximum FBs content was $4920 \mu \mathrm{g} \mathrm{kg}^{-1}$. This high concentration is unusual in Poland and may have a significant effect on the health and performance of farm animals, especially swine and horses [17].

Different strategies have been adopted to reduce Fusarium mycotoxin contamination in cereals [18]. A more economical and environmentally attractive option is the use of biological control agents (BCAs) which act as natural antagonists to Fusarium.

Beauveria bassiana, Sarocladium zeae, and Lecanicillium lecanii are endophytes of maize and some other plant species and are proved to be entomopathogenic endophytes that are used in the control of pests under field and laboratory conditions [19-21]. Trichoderma spp. are among the most studied and promising microorganisms used in a biocontrol system [22-24]. Species of the genus Trichoderma (teleomorph Hypocrea) are found in many ecosystems, but the most common and natural habitat of these fungi is soil [23].

Therefore, the aim of this study was to investigate the occurrence of Fusarium spp., Trichoderma spp., S. zeae, and L. lecanii in maize kernels collected from two localities in Poland (Greater Poland and Silesia region) during four seasons (2014-2017). Additionally, our hypothesis assumed that naturally occurring endophytes exclude pathogens or/and could decrease the toxin concentrations. The obtained results could be a valuable source of information on the possible use of endophytic fungi in biological plant protection against pathogens.

\section{Results and Discussion}

\subsection{Occurrence of Fusarium, Trichoderma spp., S. zeae, and L. lecanii in Two Maize Producing Localities in Poland}

A significant difference was found in the frequency of the two Fusarium spp. that commonly infect maize ears, namely F. subglutinans and F. verticillioides. Samples originating from locality 1 was dominated by F. subglutinans-frequency $54.5-77.2 \%$ in all the four years of study (Table 1). The frequency of F. verticillioides was found to be $45.4 \%$ in 2014 and $11.8-18.2 \%$ during $2015-2017$.

Table 1. Frequency of F. subglutinans and F. verticillioides (in \%) in maize ear rot in two localities in Poland during 2014-2017.

\begin{tabular}{ccccc}
\hline \multirow{2}{*}{ Year } & \multicolumn{2}{c}{ Locality 1 (Greater Poland Region) } & \multicolumn{2}{c}{ Locality 2 (Silesia Region) } \\
\cline { 2 - 5 } & F. subglutinans & F. verticillioides & F. subglutinans & F. verticillioides \\
\hline 2014 & 54.5 & 45.4 & 9.3 & 47.7 \\
2015 & 60.0 & 13.3 & 4.0 & 56.0 \\
2016 & 55.8 & 11.8 & 0.0 & 57.1 \\
2017 & 77.2 & 18.2 & 21.8 & 59.4 \\
\hline
\end{tabular}


In samples collected from locality 2 , the frequency of $F$. verticillioides was significantly higher at $47.7 \%, 56.0 \%, 57.1 \%$, and up to $59.4 \%$ in years $2014,2015,2016$, and 2017 , respectively. The frequency of $F$. subglutinans in the same locality was $0 \%$ in 2016 and $9.3 \%, 4.0 \%$, and $21.8 \%$ in years 2014,2015 , and 2017, respectively.

In contrast, the frequency of trichothecenes and zearalenone producing species $F$. graminearum and F. culmorum in Poland in the years 1985-2014 was below 16\%. In addition, Fusarium poae was quite frequent $(0-45.7 \%)$ [11]. The above-mentioned species were found in high frequency in countries with a warmer climate [13]. Fusarium poae frequency was $9.2-26 \%$ and this species contributes to the accumulation of beauvericin and enniatins [25].

In addition to F. subglutinans and F. verticillioides, the present study identified the presence of T. atroviride, Sarocladium zeae, and Lecanicillium lecanii in the maize samples. Trichoderma atroviride species were found in 50 of 369 maize kernels, collected in Poland during 2014-2017 seasons (Table 2). In particular, a high percentage of Trichoderma spp. was found in 2014, i.e., in 31 samples. Abundant masses of green spores of Trichoderma were found in all maize ears in six samples. In the remaining 46 samples, Trichoderma spp. grew together with Fusarium spp. on agar plates containing SNA medium. As reported by Jaklitsch [26], T. atroviride is mostly found in Europe (Austria and France) and Central and North America, where it is mostly isolated from soil and also found as a contaminant of other Hypocrea spp.

Table 2. Occurrence of Trichoderma atroviride, Sarocladium zeae, and Lecanicillium lecanii species in maize ears with significant Fusarium ear rot in Poland during 2014-2017 seasons.

\begin{tabular}{cccc}
\hline Year & $\begin{array}{c}\text { Numbers of } \\
\text { Examined Ears }\end{array}$ & $\begin{array}{c}\text { Trichoderma } \\
\text { atroviride* }\end{array}$ & $\begin{array}{c}\text { Sarocladium zeae and } \\
\text { Lecanicillium lecanii* }^{*} \\
\text { Numbers of Positive Ears }\end{array}$ \\
\hline 2014 & 100 & 31 & 1 \\
2015 & 83 & 1 & 35 \\
2016 & 58 & 1 & 8 \\
2017 & 48 & 17 & 16 \\
total & 289 & 50 & 60 \\
\hline
\end{tabular}

\footnotetext{
* Molecular identification of 18 isolates confirmed the following species: Trichoderma atroviride in six isolates,
} Sarocladium zeae in seven isolates, and Lecanicillium lecanii in five isolates

In our previous studies in Poland, we identified 14 taxa of Trichoderma in various substrates, and T. harzianum was the prevalent species $[27,28]$. Trichoderma atroviride, in contrast, accounted for a minor portion of the isolated strains. One of these strains, namely AN35, was isolated from a maize ear sample in 2005. The T. atroviride AN35 isolate exhibited antagonistic properties against several toxigenic Fusarium spp., and reduced the amount of produced mycotoxins, such as deoxynivalenol and zearalenone, in dual-culture bioassay [29-31]. The same isolate was the most efficient producer of 6-PAP under laboratory conditions. 6-PAP inhibited the growth of several Fusarium spp. when spiked per plug from 0.1 to $2 \mu \mathrm{g}$ on PDA medium [32]. This is the second report where T. atroviride species was isolated from maize kernels in Poland. Most of the existing literature describes the occurrence of T. harzianum in maize seeds [33-35].

In representative samples, the species $S$. zeae and L. lecanii were identified using DNA assays. However, in eight samples in 2015, only S. zeae was found and no Fusarium spp. were detected.

Strains of L. lecanii are known components of bioinsecticides, which are produced on a commercial scale mostly in Asia, India, and South America [21]. In previous studies, S. zeae and L. lecanii were identified as members of Acremonium strictum clade (previously Verticillium complex). A more detailed description of the above-mentioned two endophytes was obtained after the use of a phylogenetic approach [36]. Because these endophytes have a very slow growth rate, many difficulties were encountered while isolating their representative strains, especially when they were present in the same maize kernels together with Fusarium spp. Moreover, it was rather impossible to isolate them 
when fast-growing Trichoderma spp. were also present in the same maize kernels. Both endophytes are difficult to isolate using procedures described in most previous studies. Low-nutrient agar SNA prepared according to Nirenberg [37] was found to be particularly useful to isolate and identify all the above-mentioned fungi species from maize kernels. Lecanicillium lecanii produced vertilecanins, and Acremonium zeae produced dihydroresorcylides [38,39].

Fusarium verticillioides may be a primary causal agent of disease, a secondary invader or an endophyte, and systemically colonizes kernels. The fungus infects the emerging maize seedlings, the maturing plant, and the new kernel. This species is also frequently recovered from healthy maize seeds and has been known for many years to be an endophyte of maize [40].

It has been shown that another endophyte of maize, $A$. zeae, is a producer of antibiotics that inhibit F. verticillioides and Aspergillus flavus [41]. Recently, isolates of this species were renamed as Sarocladium zeae [39,42]. Most recently, a comparison of Sarocladium spp. was reported by Yeh and Kirschner [43]. In addition, the authors derived the phylogenetic tree of Sarocladium spp., and identified a new endophyte $S$. spinificis occurring in grasses in Taiwan.

The interaction of $F$. verticillioides species with maize plant and with other fungi, including the pathogens F. graminearum and F. poae, and with endophytes, such as S. zeae (formerly A. zeae), and hyperparasites, such as Trichoderma, is very complex and may influence the final contamination of kernels with fumonisins and other mycotoxins under field conditions.

\subsection{Mycotoxin Accumulation}

The amount of mycotoxin accumulated in maize kernels in the two localities with F. subglutinans (F. temperatum) and F. verticillioides as the prevalent species is given in Table 3. A significantly higher amount of BEA was found in samples from locality 1-Greater Poland-except in the 2016 harvest. The highest amount of BEA content was recorded in 2015 in locality 1 where the maximum and average concentrations were 1731.55 and $201.33 \mathrm{\mu g} \mathrm{g}^{-1}$, respectively. The lowest toxin content occurred in 2017 in both studied locations. In locality 1, despite a large number of positive samples $(95.24 \%)$, the average toxin content was $32.25 \mu^{-1} \mathrm{~g}^{-1}$. In locality 2 , the value was even lower and reached an average of $1.84 \mu \mathrm{g} \mathrm{g}^{-1}$, with a maximum value of $24.14 \mu \mathrm{g} \mathrm{g}^{-1}$.

Table 3. Average and maximum content $\left[\mu \mathrm{g} \mathrm{g}^{-1}\right]$ of beauvericin and fumonisins in Fusarium contaminated kernels in maize samples collected from two localities (Locality 1-Greater Poland region, Locality 2-Silesia region) in Poland during 2014-2017.

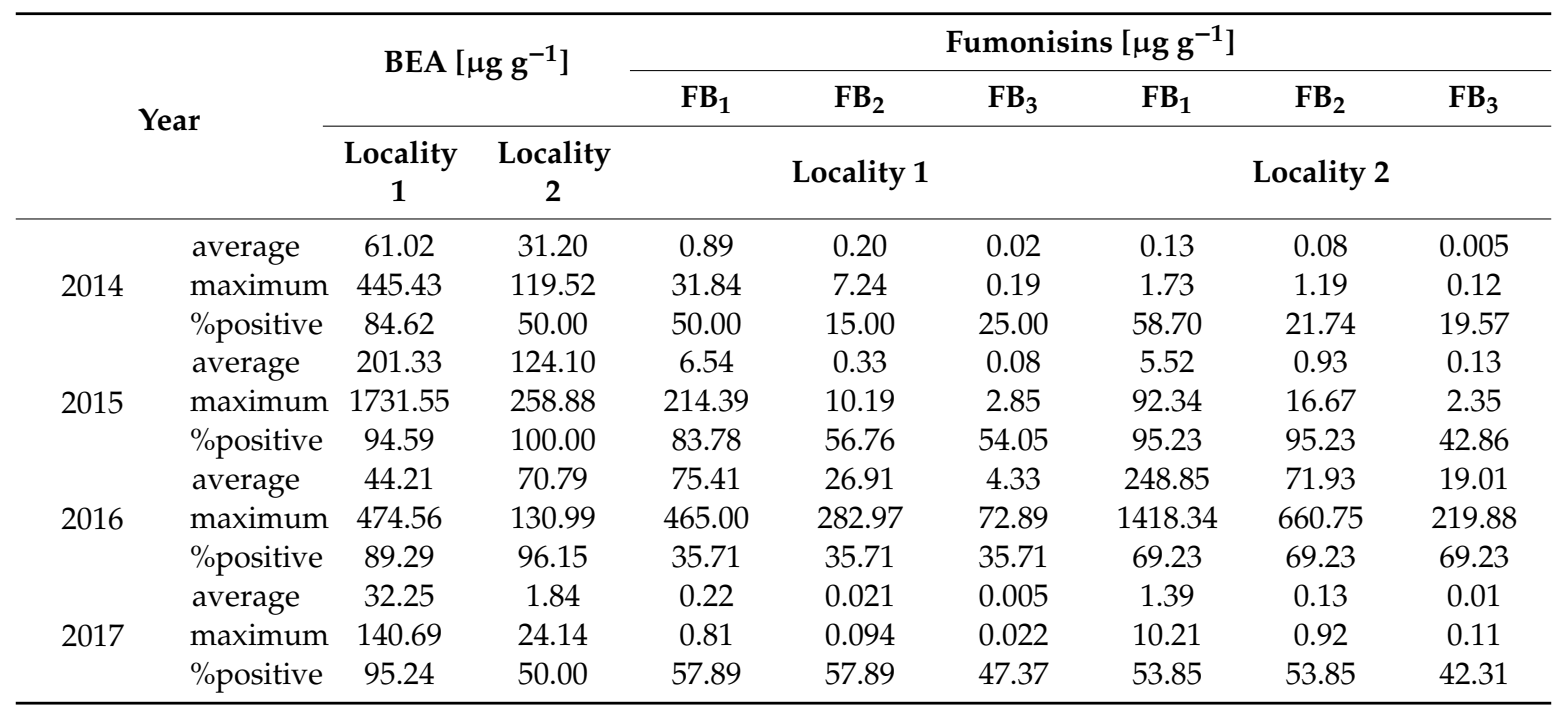

In China, BEA was the predominant toxin in terms of the frequency and concentration in corn. It was found that $82.3 \%$ of samples were contaminated by BEA with the levels ranging from $0.04 \mathrm{mg} \mathrm{g}^{-1}$ 
to $1006.56 \mathrm{mg} \mathrm{g}^{-1}$ [44]. The occurrence of beauvericin was also investigated in corn kernel samples collected in Croatia [45]. The crop was found to be contaminated with a mean beauvericin content of $393 \mathrm{ng} \mathrm{g}^{-1}$ and the highest level of $1864 \mathrm{ng} \mathrm{g}^{-1}$.

The amount of fumonisins $B_{1}, B_{2}$, and $B_{3}$ depends on both the location and year of sampling. In this regard, particular attention should be given to the amount of fumonisins in the years 2016 and 2017. The year 2016 was characterized by very high $\mathrm{FB}_{1}$ content in both localities, reaching up to $248.85 \mathrm{\mu g} \mathrm{g}^{-1}$ on average in locality 2 when the maximum value was $1418.34 \mu \mathrm{g} \mathrm{g}^{-1}$. In 2016, a significant difference in the frequency of fumonisin occurrence was also noted. In locality 1 , these toxins were found in approximately $36 \%$ of all the tested samples, whereas in locality 2 , the percent of positive samples was almost twice high than that in locality 1. In contrast, the year 2017 was characterized by a very low content of fumonisins, especially in locality 1 where the maximum $\mathrm{FB}_{1}$ content in the FDK fraction was $0.81 \mu \mathrm{g} \mathrm{g}^{-1}$. The remaining fumonisins- $\mathrm{FB}_{1}$ and $\mathrm{FB}_{2}-$ occurred at the maximum content of $0.094 \mu \mathrm{g} \mathrm{g}^{-1}$ and $0.022 \mu \mathrm{g} \mathrm{g}^{-1}$, respectively. In locality $2, \mathrm{FB}_{1}, \mathrm{FB}_{2}$, and $\mathrm{FB}_{3}$ content in the same year was $10.21,0.92$, and $0.11 \mathrm{gg} \mathrm{g}^{-1}$, respectively.

According to Gromadzka et al. [12], in Poland from 2005 to 2014, kernels naturally infected by F. verticillioides and F. proliferatum contained (in mg kg${ }^{-1}$ ) up to 710 of $\mathrm{FB}_{1}, 209.72$ of $\mathrm{FB}_{2}$, and 35.72 of $\mathrm{FB}_{3}$. In Italy [46], where the climate is much warmer than that in Poland, the mean levels of fumonisin contamination were remarkably high in years 2006-2008, with the highest value of $10.90 \mathrm{mg} \mathrm{kg}^{-1}$ and the lowest value of $4.80 \mathrm{mg} \mathrm{kg}^{-1}$. The issue of fumonisin contamination is particularly critical in Africa, where maize is the staple food for the human population and is consumed without any processing. In Eastern and Southern Africa, $\mathrm{FB}_{1}$ was detected at concentrations ranging from 0.002 to $1.91 \mathrm{mg} \mathrm{kg}^{-1}$, while the sum of fumonisin concentrations in the same samples ranged from 0.002 to $2.73 \mathrm{mg} \mathrm{kg}^{-1}$ [47].

It is difficult to compare the obtained results in Poland with those obtained in other countries because the final amount of mycotoxins accumulated in maize kernels depends on several factors, such as the toxigenic ability of Fusarium spp. [13], maize hybrids produced and their susceptibility to MER [7,48], interaction among the Fusarium spp. population in the given area-frequently four species were identified in the examined MER samples [11], the population of European corn borer (ECB) and other pests in maize ears before harvest [6,48,49], and the interaction of Fusarium spp. with other fungi, including endophytes and competitive species such as Trichoderma or Alternaria, Cladosporium, Epicoccum, Acromoniella, and Nigrospora, [11], which are proved to be present in the same kernels (ears).

The results of our research also indicate the existence of a dependency between the occurrence of endophytic fungi and the content of mycotoxins in the maize kernels. Such trends are noticed only in the case T. atroviride (Figure 1). The presence of the other testing endophytic had no effect on toxin concentrations. Our studies were of a preliminary character and should be continued to finally confirm our research hypothesis.

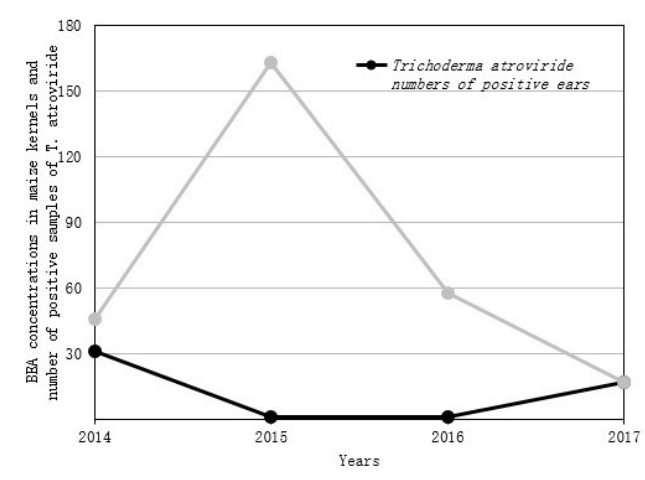

(a)

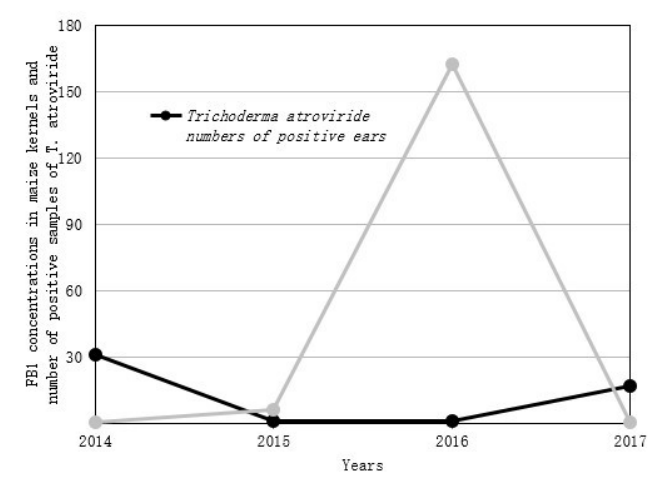

(b)

Figure 1. Influence of Trichoderma atroviride occurrence on mycotoxins content in maize samples. (a) average concentration of BEA, (b) average concentrations of fumonisin $\mathrm{FB}_{1}$. 
Biological control is a promising strategy for managing MER disease. The use of microbial biological control agents (MBCA) serves as an alternative to chemical control measures for growing pathogen-resistant crop cultivars. Trichoderma strains used as biocontrol agents are able to induce plant defense against pathogens and promote plant growth $[24,50]$. They were also found to reduce mycotoxins, in particular, zearalenone and deoxynivalenol production, in dual-culture bioassay [28-30]. Further, the use of microbial biological control agents in agriculture is rapidly increasing because of public concerns about human health, safety of crop products consumed, and impact on the environment. Our studies show that the frequent occurrence of endophytic fungi in our climate zone makes it possible to use them as biological methods of plant protection. In addition, the mycotoxins content decreased as the frequency of endophytes increased. However, further research is necessary to be able to use these fungi in modern agriculture.

\section{Materials and Methods}

\subsection{Chemicals and Reagents}

Mycotoxin standards (FBs and BEA) HPLC grade solvents and all reagents for extraction and purification process were obtained from Sigma-Aldrich (Steinheim, Germany). Water (HPLC grade) was obtained from MilliQ system (Millipore, Billerica, MA, USA).

\subsection{Fungal Isolation and Identification}

The samples of maize ears were collected in October 2014 (100 samples), 2015 (83 samples), 2016 (58 samples), and 2017 (48 samples) in two main maize growing areas in Poland (locality 1: Greater Poland $-16^{\circ} 56^{\prime} \mathrm{E}, 50^{\circ} 58^{\prime} \mathrm{N}$ and locality 2: Silesia- $52^{\circ} 48^{\prime} \mathrm{N}, 16^{\circ} 83^{\prime} \mathrm{E}$ ).

After harvesting, each sample was packed into a separate paper bag and stored at room temperature. The maize ears with Fusarium ear rot symptoms were evaluated based on the degree of kernels moldy, shrunken and discolored on a scale of $1 \%$ to $100 \%$. Subsequently, small pieces of kernels and visible mycelium from each ear were plated in duplicate on a low nutrient SNA medium and incubated at $20^{\circ} \mathrm{C}$ to identify Fusarium spp. and other fungi [37,51,52]. The hyphal tips from each culture were placed on both in Petri dishes containing potato dextrose agar and synthetic SNA low-nutrient agar. Fusarium spp. were identified according to Kwaśna et al. [52] and Leslie and Summerell [53]. Trichoderma spp. were identified according to Kubicek and Harman [54], and Lecanicillium and Sarocladium were identified according to Shinde et al. [21] and Summerbell et al. [36]. Further, the identification of the selected isolates was performed using DNA assay as described below.

\subsection{Molecular Identification}

For molecular identification, two different phylogenetic markers were selected: the internally transcribed spacer regions 1 (ITS1) and 2 (ITS2,) of the rRNA gene cluster and the fragment (fourth and fifth introns and a portion of sixth exon) of the translation-elongation factor 1-alpha (tef1) gene. Fungal isolates were grown in liquid Czapek-Dox broth medium (Sigma-Aldrich, Saint Louis, MI, USA) with the addition of yeast extract (Oxoid ${ }^{\mathrm{TM}}$ Yeast Extract Powder Thermo Fisher Scientific, Waltham, MA, USA) and streptomycin sulfate (50 $\mathrm{mg} \mathrm{L}^{-1}$, AppliChem, Darmstad, Germany) for 21 days on a rotary shaker $(120 \mathrm{rpm})$ at $25^{\circ} \mathrm{C}$. After that, mycelium was collected on filter paper in a Büchner funnel, washed with sterile water, frozen at $-20^{\circ} \mathrm{C}$, and freeze-dried. Genomic DNA was isolated using the Wizard ${ }^{\circledR}$ Genomic DNA Purification Kit (Promega, Madison, WI, USA). Amplicons were produced with the primer combination ITS4 and ITS5 [55] for the ITS region and Ef728M [56] and TEF1LLErev [26] for the tef1 fragment under the following conditions: initial denaturation at $94{ }^{\circ} \mathrm{C}$ for $5 \mathrm{~min}, 35$ cycles of denaturation at $94{ }^{\circ} \mathrm{C}$ for $45 \mathrm{~s}$, annealing at $58^{\circ} \mathrm{C}$ for ITS region, or at $63^{\circ} \mathrm{C}$ for the tef1 gen fragment for $45 \mathrm{~s}$, extension at $72{ }^{\circ} \mathrm{C}$ for $1 \mathrm{~min}$, final extension at $72{ }^{\circ} \mathrm{C}$ for $10 \mathrm{~min}$. The PCR reaction was carried out in $25 \mu \mathrm{L}$ reaction volumes with $1 \mu \mathrm{L} 50 \mathrm{ng} \mu \mathrm{L}^{-1}$ of genomic DNA, $2.5 \mu \mathrm{L} 10 \times$ DreamTaq green buffer (includes $20 \mathrm{mM} \mathrm{MgCl}_{2}$, Thermo Fisher Scientific, Waltham, MA, 


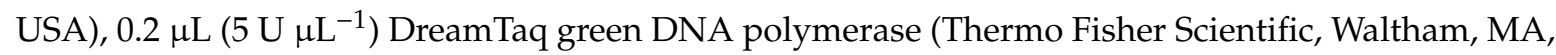
USA), $0.2 \mu \mathrm{L} 100 \mathrm{mmol} \mathrm{L}^{-1}$ of each primer, $0.25 \mathrm{mM}$ dNTP mix (Sigma-Aldrich, Saint Louis, MI, USA), $19.35 \mu \mathrm{L}$ sterile distilled water, using a C1000 Thermal Cycler (Bio-Rad, Hercules, CA, USA). Ten $\mu \mathrm{L}$ of PCR product was analyzed on $1.5 \%$ agarose gel (BioShop, Burlington, ON, Canada) in $1 \times$ TBE buffer (BioShop, Burlington, ON, Canada) and stained with Midori green advance DNA stain (NIPPON Genetics EUROPE GmbH, Dueren, Germany), visualized under UV light, and photographed (Syngene UV visualizer). Gene Ruler 100-bp Plus DNA Ladder $\left(0,5 \mu \mathrm{g} \mu \mathrm{L}^{-1}\right.$, Thermo Fisher Scientific, Waltham, MA, USA) was used as a size standard. Samples that produced a clear visible band were prepared for sequencing by purifying PCR product $(5 \mu \mathrm{L})$ with exonuclease $\mathrm{I}\left(0.5 \mu \mathrm{L}, 1 \mathrm{U}_{\mu} \mathrm{L}^{-1}\right.$, Thermo Fisher Scientific, Waltham, MA, USA) and shrimp alkaline phosphatase $\left(2 \mu \mathrm{L}, 1 \mathrm{U} \mathrm{LL}^{-1}\right.$, Thermo Fisher Scientific, Waltham, MA, USA), incubating $30 \mathrm{~min}$ at $37^{\circ} \mathrm{C}$, denaturing $15 \mathrm{~min}$ at $80^{\circ} \mathrm{C}$ and, cooling down to $4{ }^{\circ} \mathrm{C}$. The 400-bp ITS and 1200-bp tef1 amplicon purification and sequencing were the same as that described by Błaszczyk et al. [27]. Sequences editing and assembling were performed using the software Chromas v. 1.43 (version 1.43, Technelysium Pty Ltd, Cordelia St, South Brisbane QLD 4101, Australia, 2004). For species identification, the sequences were matched against the nucleotide database using BLASTn (http://blast.ncbi.nlm.nih.gov/).

\subsection{Sample Preparation, Extraction and HPLC Analysis}

A detailed procedure of extraction and purification of mycotoxins (FBs and BEA) was reported previously $[16,56]$. The samples before fumonisins $\left(\mathrm{FB}_{1}, \mathrm{FB}_{2}\right.$, and $\left.\mathrm{FB}_{3}\right)$ analysis were derivatized with $o$-phthalaldehyde (OPA) reagent for $3 \mathrm{~min}$. Methanol: sodium dihydrogen phosphate ( $0.1 \mathrm{M}$ in water) solution $(77: 23, v / v)$ adjusted to $\mathrm{pH} 3.35$ with phosphoric acid was used as the mobile phase with a flow rate of $0.6 \mathrm{~mL} \cdot \mathrm{min}^{-1}$. A Waters 2695 apparatus (Waters Division of Millipore, Milford, MA, USA) and a Waters 2475 fluorescence detector $\left(\lambda_{\mathrm{EX}}=335 \mathrm{~nm}\right.$ and $\left.\lambda_{\mathrm{EM}}=440 \mathrm{~nm}\right)$ with a C-18 Nova Pak column $(3.9 \times 150 \mathrm{~mm})$ were used for fumonisins analysis. HPLC analysis of BEA was performed using a Waters 2695 system equipped with a Waters 2996 Array Detector (at $205 \mathrm{~nm}$ ) with C-18 Nova Pak column $(3.9 \times 150 \mathrm{~mm})$. Samples were eluted with acetonitrile: water $(70: 30, v / v)$ at a constant flow of $1 \mathrm{~mL} \mathrm{~min}{ }^{-1}$ for $45 \mathrm{~min}$. The limits of detection were 10 and $8 \mathrm{ng} \mathrm{g}^{-1}$ for FBs and BEA, respectively. The obtained positive results (on the basis of retention times) were confirmed by HPLC analysis and compared with the relevant calibration curve (correlation coefficients for $\mathrm{FB}_{1}, \mathrm{FB}_{2}, \mathrm{FB}_{3}$, and $\mathrm{BEA}$ were 0.9967, 0.9983, 0.9966, 0.9991, respectively). Recovery rates for $\mathrm{FB}_{1}, \mathrm{FB}_{2}, \mathrm{FB}_{3}$, BEA were 93, 96, 87, and $91 \%$, respectively.

Author Contributions: conceptualization, J.C. and K.G.; mycological analysis, J.C. and L.B.; molecular analysis, L.B.; chemical analysis, A.W. and K.G.; data curation, J.C. and K.G.; writing- original draft preparation, J.C.; K.G., L.B.; A.W.; writing-review and editing, K.G.; J.C.; project administration, A.W.; funding acquisition, A.W.

Funding: This research was funded by the Polish National Science Centre, grant number 2014/15/B/NZ9/02169.

Acknowledgments: The funders had no role in the design of the study; in the collection, analyses, or interpretation of data; in the writing of the manuscript, or in the decision to publish the results.

Conflicts of Interest: Author Karolina Gromadzka declares that she has no conflict of interest. Author Jerzy Chełkowski declares that he has no conflict of interest. Author Lidia Błaszczyk declares that she has no conflict of interest. Author Agnieszka Waśkiewicz declares that she has no conflict of interest.

\section{References}

1. Ksiezak, J.; Bojarczuk, J. The economic assessment of maize cultivation on pre-sowing tillage system. Acta Sci. Pol. Agric. 2010, 9, 55-67.

2. White, D.G. Compendium of Corn Diseases, 3rd ed.; American Phytopathological Society Press: St Paul, MN, USA, 1999.

3. Wit, M.; Warzecha, R.; Mirzwa-Mroz, E.; Jabłonska, E.; Ochodzki, P.; Waskiewicz, A.; Wakulinski, W. Susceptibility of flint and dent maize ears to Fusarium species. Phytopathologia 2011, 60, 35-45. 
4. Bottalico, A. Fusarium diseases of cereals: Species complex and related mycotoxins profiles in Europe. J. Plant Pathol. 1998, 80, 85-103.

5. Bottalico, A.; Perrone, G. Toxigenic Fusarium species and mycotoxins associated with head blight in small grain cereals in Europe. Eur. J. Plant Pathol. 2002, 108, 998-1003. [CrossRef]

6. Munkvold, G.P. Epidemiology of Fusarium diseases and their mycotoxins in maize ears. Eur. J. Plant Pathol. 2003, 109, 705-713. [CrossRef]

7. Pascale, M.; Visconti, A.; Chełkowski, J. Ear rot susceptibility and mycotoxin contamination of maize hybrids inoculated with Fusarium species under field conditions. Eur. J. Plant Pathol. 2002, 108, 645-651. [CrossRef]

8. Bacon, C.W.; Bennett, R.M.; Hinton, D.M.; Voss, K.A. Scanning electron microscopy of Fusarium moniliforme within asymptomatic corn kernels and kernels associated with equine leukoencephalomalacia. Plant Dis. 1992, 76, 144-148. [CrossRef]

9. Sobek, E.A. Associations between corn Insects and Symptomatic and Asymptomatic Corn Kernel Infection by Fusarium Moniliforme. Master's Thesis, Iowa State University, Ames, Ames, IA, USA, 1996.

10. Chełkowski, J. Distribution of Fusarium species and their mycotoxins in cereal grains. In Mycotoxins in Food and Agricultural Safety; Sinha, K., Bathnagar, D., Eds.; Marcel Dekker: New York, NY, USA, 1998; pp. 45-64.

11. Gromadzka, K.; Górna, K.; Chełkowski, J.; Waśkiewicz, A. Mycotoxins and related Fusarium species in preharvest maize ear rot in Poland. Plant Soil Environ. 2016, 62, 348-354. [CrossRef]

12. Gromadzka, K.; Wit, M.; Górna, K.; Chełkowski, J.; Waśkiewicz, A.; Ochodzki, P.; Warzecha, R. Fumonisins and related Fusarium species in pre-harvest maize ear rot in Poland. Cereal Res. Commun. 2017, 45, $93-103$. [CrossRef]

13. Logrieco, A.; Mule, G.; Moretti, A.; Bottalico, A. Toxigenic Fusarium species and mycotoxins associated with maize ear rot in Europe. Eur. J. Plant Pathol. 2002, 108, 597-609. [CrossRef]

14. Chełkowski, J. Mycotoxins associated with corn cob fusariosis. In Fusarium-Mycotoxins, Taxonomy and Pathogenicity; Chełkowski, J., Ed.; Elsevier: Amsterdam, The Netherlands, 1989; pp. 53-62.

15. Tomczak, M.; Wiśniewska, H.; Stępień, Ł.; Kostecki, M.; Chełkowski, J.; Goliński, P. Deoxynivalenol, nivalenol and moniliformin occurrence in wheat samples with scab symptoms in Poland (1998-2000). Eur. J. Plant Pathol. 2002, 108, 625-630. [CrossRef]

16. Goliński, P.; Waśkiewicz, A.; Wiśniewska, H.; Kiecana, I.; Mielniczuk, E.; Gromadzka, K.; Kostecki, M.; Bocianowski, J.; Rymaniak, E. Reaction of winter wheat (Triticum aestivum L.) cultivars to infection with Fusarium spp.: Mycotoxin contamination in grain and chaff. Food Addit. Contam. 2010, 27, 1015-1024.

17. NUTRIAD Mycotoxin Survey. 2017. Available online: https://nutriad.com/wpcontent/uploads/2018/01/ Article_Nutriad_Poland_2017_Mycotoxin_Survey_Maize.pdf (accessed on 10 January 2018).

18. Ferrigo, D.; Raiola, A.; Rasera, R.; Causin, R. Trichoderma harzianum seed treatment controls Fusarium verticillioides colonization and fumonisin contamination in maize under field conditions. Crop Prot. 2014, 65, 51-56. [CrossRef]

19. Vega, F.E.; Posada, F.; Aime, M.C.; Pava-Ripoll, M.; Infante, F.; Rehner, S.A. Entomopathogenic fungal endophytes. Biol. Control 2008, 46, 72-92. [CrossRef]

20. Vidal, S.; Jaber, L.R. Entomopathogenic fungi as endophytes: Plant-endophyte-herbivore interactions and prospects for use in biological control. Curr. Sci. 2015, 109, 46-53.

21. Shinde, S.V.; Patel, K.G.; Purohit, M.S.; Pandya, J.R.; Sabalpara, A.N. Lecanicillium lecanii (Zimm) Zare and Gams an important biocontrol agent for the management of insect pests-A Review. Agric. Rev. 2010, 31, 235-252.

22. Lorito, M.; Woo, S.L.; Harman, G.E.; Monte, E. Translational research on Trichoderma: From 'omics to the field. Annu. Rev. Phytopathol. 2010, 48, 395-417. [CrossRef]

23. Druzhinina, I.S.; Seidl-Seiboth, V.; Herrera-Estrella, A.; Horwitz, B.A.; Kenerley, C.M.; Monte, E.; Mukherjee, P.K.; Zeilinger, S.; Grigoriev, I.V.; Kubicek, C.P. Trichoderma: The genomics of opportunistic success. Nat. Rev. Microbiol. 2011, 9, 749-759. [CrossRef]

24. Mukherjee, P.K.; Horwitz, B.A.; Kenerley, C.M. Secondary metabolism in Trichoderma-A genomic perspective. Microbiology 2012, 158, 35-45. [CrossRef]

25. Chełkowski, J.; Ritieni, A.; Wisniewska, H.; Mule, G.; Logrieco, A. Occurrence of toxic hexadepsipeptides in preharvest maize ear rot infected by Fusariun poae in Poland. J. Phytopathol. 2007, 155, 8-12. [CrossRef]

26. Jaklitsch, W.M.; Komon, M.; Kubicek, C.P.; Druzhinina, I.S. Hypocrea voglmayrii sp. nov. from the Austrian Alps represents a new phylogenetic clade in Hypocrea/Trichoderma. Mycologia 2005, 97, 1365-1378. [CrossRef] 
27. Błaszczyk, L.; Popiel, D.; Chełkowski, J.; Koczyk, G.; Samuels, G.J.; Sobieralski, K.; Siwulski, M. Species diversity of Trichoderma in Poland. J. Appl. Genet. 2011, 52, 233-243. [CrossRef]

28. Błaszczyk, L.; Basińska, A.; Ćwiek, H.; Gromadzka, K.; Popiel, D.; Stępień, . Suppressive effect of Trichoderma on toxigenic Fusarium species. Pol. J. Microbiol. 2017, 1, 85-100. [CrossRef]

29. Buśko, M.; Chelkowski, J.; Popiel, D.; Perkowski, J. Solid substrate bioassay to evaluate impact of Trichoderma on trichothecene mycotoxin production by Fusarium species. J. Sci. Food Agric. 2008, 88, 536-541. [CrossRef]

30. Gromadzka, K.; Chełkowski, J.; Popiel, D.; Kachlicki, P.; Kostecki, M.; Goliński, P. Solid substrate bioassay to evaluate the effect of Trichoderma and Clonostachys on the production of zearalenone by Fusarium species. World Mycotoxin J. 2009, 2, 45-52. [CrossRef]

31. Popiel, D.; Koczyk, G.; Dawidziuk, A.; Gromadzka, K.; Błaszczyk, L.; Chełkowski, J. Zearalenone lactonohydrolase activity in Hypocreales and its evolutionary relationships within the epoxide hydrolase subset of a/b-hydrolases. BMC Microbiol. 2014, 14, 82. [CrossRef]

32. Jeleń, H.; Błaszczyk, L.; Chełkowski, J.; Rogowicz, K.; Strakowska, J. Formation of 6-n-pentyl-2H-pyran-2-one (6-PAP) and other volatiles by different Trichoderma species. Mycol. Prog. 2013, 13, 589-600. [CrossRef]

33. Lumi Abe, C.A.; Bertechini Faria, C.; Castro, F.F.; Souza, S.R.; Santos, F.C.; Silva, C.N.; Tessmann, D.J.; Barbosa-Tessmann, I.P. Fungi isolated from maize (Zea mays L.) grains and production of associated enzyme activities. Ed. Ritva Tikkanen. Int. J. Mol. Sci. 2015, 16, 15328-15346. [CrossRef]

34. Bhattacharya, K.; Raha, S. Deteriorative changes of maize, groundnut and soybean seeds by fungi in storage. Mycopathologia 2002, 155, 135-141. [CrossRef]

35. Niaz, I.; Dawar, S. Detection of seed borne mycoflora in maize (Zea mays L.). Pak. J. Bot. 2009, 41, 443-451.

36. Summerbell, R.C.; Gueidan, C.; Schreors, H.J.; de Hoog, G.S.; Staring, M.; Arocha Rosete, Y.; Guarro, J.; Scott, J.A. Acremonium phylogenetic overview and revision of Gliomastix, Sarocladium, and Trichothecium. Stud. Mycol. 2011, 68, 139-162. [CrossRef]

37. Nirenberg, H.I. A simplified method for identifying Fusarium spp. occurring on wheat. Can. J. Bot. 1981, 59, 1599-1609. [CrossRef]

38. Soman, A.G.; Gloer, J.B.; Angawi, R.F.; Wicklow, D.T.; Dowd, P.F. Vertilecanins: new phenopicolinic acid analogues from Verticillium lecanii. J. Nat. Prod. 2001, 64, 189-192. [CrossRef]

39. Poling, S.M.; Wicklow, D.T.; Rogers, K.D.; Gloer, J.B. Acremonium zeae, a protective endophyte of maize, produces dihydroresorcylide and 7-hydroxydihydroresorcylides. J. Agric. Food Chem. 2008, 56, 3006-3009. [CrossRef]

40. Pamphile, J.A.; Azwedo, J.L. Molecular characterization of endophytic strains of Fusarium verticillioides (=Fusarium moniliforme) from maize (Zea mays. L). World J. Microbiol. Biotechnol. 2002, 18, 391-396. [CrossRef]

41. Wicklow, D.T.; Roth, S.; Deyrup, S.T.; Gloer, J.B. A protective endophyte of maize: Acremonium zeae antibiotics inhibitory to Aspergillus flavus and Fusarium verticillioides. Mycol. Res. 2005, 109, 610-618. [CrossRef]

42. Giraldo, A.; Gené, J.; Cano, J.; Hoog, S.; Guarro, J. Two new species of Acremonium from Spanish soils. Mycologia 2012, 104, 1456-1465. [CrossRef]

43. Yeh, Y.H.; Kirschner, R. Sarocladium spinificis, a new endophytic species from the coastal grass Spinifex littoreus in Taiwan. Bot. Stud. 2014, 55, 25. [CrossRef]

44. Han, X.; Xu, W.; Zhang, J.; Xu, J.; Li, F. Natural occurrence of beauvericin and enniatins in corn- and wheat-based samples harvested in 2017 collected from Shandong Province, China. Toxins 2019, 11, 9. [CrossRef]

45. Jurjevic, Z.; Solfrizzo, M.; Cvjetkovic, B.; De Girolamo, A.; Visconti, A. Occurrence of beauvericin in corn from Croatia. Food Technol. Biotechnol. 2002, 40, 91-94.

46. Berardo, N.; Lanzanova, C.; Locatelli, S.; Laganà, P.; Verderio, A.; Motto, M. Levels of total fumonisins in maize samples from Italy during 2006-2008. Food Addit. Contam. Part B 2011, 4, 116-124. [CrossRef]

47. Waalwijk, C.; Koch, S.; Ncube, E.; Allwood, J.; Flett, B.C.; de Vries, I.; Khema, G.H.J. Quantitativedetection of Fusarium spp. and its correlation with fumonisin content in maize from South African subsistence farmers. World Mycotoxins J. 2008, 1, 37-45. [CrossRef]

48. Munkvold, G.P.; Hellmich, R.L.; Showers, W.B. Reduced Fusarium ear rot and symptomless infection in kernels of maize genetically engineered for European corn borer resistance. Phytopathology 1997, 87, 1071-1077. [CrossRef]

49. Avantaggiato, G.; Quaranta, F.; Desiderio, E.; Visconti, A. Fumonisin contamination of maize hybrids visibly damaged by Sesamia. J. Sci. Food Agric. 2003, 83, 13-18. [CrossRef] 
50. Hermos, R.; Viterbo, A.; Chet, I.; Monte, E. Plant-beneficial effects of Trichoderma and of its genes. Microbiology 2012, 158, 17-25. [CrossRef]

51. Kostecki, M.; Grabarkiewicz-Szczęsna, J.; Chełkowski, J.; Wiśniewska, H. Beauvericin and moniliformin production by Polish isolates of Fusarium subglutinans and natural co-occurrence of both mycotoxins in maize samples. Microbiol.-Aliments-Nutr. 1995, 13, 67-70.

52. Kwaśna, H.; Chełkowski, J.; Zajkowski, P. Fusarium (Sierpik) I; Institute of Botany, Polish Academy of Sciences: Warszawa, Poland, 1991.

53. Leslie, J.F.; Summerell, B.A. The Fusarium Laboratory Manual; Blaackwell Publishing: Hoboken, NJ, USA, 2006; p. 388.

54. Carbone, I.; Kohn, L.M. A method for designing primer sets for speciation studies in filamentous ascomycetes. Mycologia 1999, 91, 553-556. [CrossRef]

55. Thompson, J.D.; Higgins, D.G.; Gibson, T.J. CLUSTAL W: Improving the sensitivity of progressive multiple sequence alignment through sequence weighting, position-specific gap penalties and weight matrix choice. Nucleic Acids Res. 1994, 22, 4673-4680. [CrossRef]

56. Jestoi, M.; Rokka, M.; Yli-Mattila, T.; Parikka, P.; Rizzo, A.; Peltonen, K. Presence and concentrations of the Fusarium-related mycotoxins beauvericin, enniatins and moniliformin in finish grain samples. Food Addit. Contam. 2004, 21, 794-802. [CrossRef]

(C) 2019 by the authors. Licensee MDPI, Basel, Switzerland. This article is an open access article distributed under the terms and conditions of the Creative Commons Attribution (CC BY) license (http://creativecommons.org/licenses/by/4.0/). 